\title{
STATISTICAL ANALYSES OF BIOAEROSOL CONCENTRATION AT MUNICIPAL LANDFILL SITE
}

\author{
ANALIZA STATYSTYCZNA ZAWARTOŚCI BIOAEROZOLU \\ W OBRĘBIE SKŁADOWISKA ODPADÓW KOMUNALNYCH
}

\begin{abstract}
Air microbial quality of the municipal landfill site and in its surroundings was evaluated. Adverse impact of the municipal landfill site in Tarnow on the atmospheric environment was noted, despite the use of correct waste disposal technology. The sampling site and season of the year significantly affected the numbers of various groups of air microorganisms at the municipal landfill site and in its vicinity. For most cases, the effects of the sampling site on the microbial numbers were stronger than that of the season of the year. In this study, higher microbial numbers were observed at the sampling sites located in the area of the active landfill site compared to those located in its vicinity. The obtained results indicate, that despite the lack of current limits for bioaerosol levels the landfill site, even after its closing and reclamation, may still not be a suitable place for any public usage. Therefore, any regular microbiological studies of air should be carried out for a long time both at the area of landfill site and in its vicinity. These results could allow to define the time, when the landfill site become stable, regarding the numbers of microorganisms released to air.
\end{abstract}

Keywords: bioaerosol, atmospheric environment, municipal landfill site, microorganisms

In many countries, establishing municipal landfill site is still the only way of waste management. Wastes are always treated as a substantial hazard for people and the environment, regardless of their origin, properties and possible usefulness. It is to be stressed, that the range of this hazard is determined by various factors as, quantity and nature of deposited wastes, the kind, shape and age of a landfill site, a waste disposal technology, safety protection and recruitment of the landfill site, soil properties and meteorological conditions [1-6]. Microbiological contaminants are mainly bacteria, microscopic fungi, viruses, plants pollen and different substances produced by microorganisms, which are called bioaerosol or organic dust [7]. Bioaerosols are naturally or artificially produced aggregation of biological particles dispersed in air [8, 9]. They may consist of both live and dead cells of microorganisms as single cells or their aggregation.

\footnotetext{
${ }^{1}$ Department of Microbiology, University of Agriculture, al. A. Mickiewicza 21, 31-120 Kraków, Poland, phone +48 1266244 02, email: rrfracze@ cyf-kr.edu.pl

${ }^{2}$ Department of Microbiology, The Nicolaus Copernicus University in Torun, ul. Gagarina 9, 87-100 Toruń, Poland

${ }^{3}$ Department of Agricultural Environment Protection, University of Agriculture, al. A. Mickiewicza 21, 31-120 Kraków, Poland, phone +48 126624402

*Corresponding author: rrfracze@cyf-kr.edu.pl
} 
Size of aerosol particles suspended in the air ranges from 0.001 (bacterial endotoxins) to more than $100 \mu \mathrm{m}$ (plants pollen) [7]. Concentration of bioaerosols depends on the quantity and quality of dust particles in the air. Thus factors increasing the dust pollution also favor microorganisms' presence in the air. Under normal environmental conditions, majority of bacterial and microfungal aerosol components does not have any health hazard at their low concentrations. Long-lasting keeping up of unstabilized amounts of wastes as well as all factors increasing the dustiness on any municipal landfill site ( $e g$ waste delivery, planting with mechanical equipment, waste compacting and covering) cause formation of bioaerosol with high concentrations of microorganisms. The main source of bioaerosol at the landfill sites are municipal wastes. High share of organic wastes creates favorable conditions for existence and proliferation of many microorganisms as: bacteria, viruses, algae and fungi. The distribution of bioaerosols depends on microclimatic condition and seasonal changes of them [10-12]. The amount of air-portable microorganisms is usually higher during summer then winter but some authors reports no seasonal changes [13]. The highest concentrations of bioaerosols are usually observed directly above landfill sites and is even thousand times higher than in indoor premises (flats, public buildings) [14]. The microbiological particles are displaced quickly to long distances (even hundreds kilometers) from their sources [15]. Fate of the microbial contaminants in the air depends on their size. Particles of diameter 10-100 $\mu \mathrm{m}$ almost immediately deposit on the ground near the source of emission. Smaller particles $(0.5-10 \mu \mathrm{m})$ are passively transported with the air to long distances. Landfill sites emit spores of different fungi, and the most common are: Alternaria, Aspergillus, Cladosporium, Fusarium, Penicillium, Mucor, Rhizopus, Trichoderma [16]. The composition of fungi in the air on the landfill site is mostly consistent with the fungi species which develop on the waste. Among microorganisms present in bioaerosols are also opportunistic pathogens, which can cause diseases when host organisms immune systems fails $[17,18]$. Microorganisms which compose bioaerosols, do not proliferate in the air and depending on the environment conditions can survive for only specified period of time.

Usually, the occurrence of diseases (mainly those of the respitatory system) among municipal landfill sites workers is higher compared to other people. Live and dead cells of biological aerosol (eg thermophilic fungi and bacteria) can enhance a health hazard among the workers, frequently causing pathogenic infections, eg some allergies and asthma [19-24]. Pathogenicity and virulence of microorganisms in the air of municipal landfill sites is not stable over time. Microbial persistence in the air and their abilities to cause infectious diseases depend on species and infection types, as well as meteorological and microclimatical features (ie direction and speed of wind, temperature, humidity, atmospheric pressure, solar radiation, rainfall and statics). The relationships between the emission of microorganisms and atmospheric conditions or seasons indicate, that the range of harmful effects may change both in space and time [25-28]. Health effects caused by inhalation of various air particles, depend on their size, chemical composition, microbiological properties, as well as on the place of their deposition in the respiratory system [29]. Particles smaller than $5 \mu \mathrm{m}$ in diameter may penetrate pulmonary alveolus and cause their allergic inflammation and other dangerous diseases. It is important to remember that in all environments are polluted to some extent. Problems with contamination appear when the concentration of pollutants is higher than the normal background level characteristic for specific environment [7]. Occupational exposure limits for microbial contamination of air have not been established yet. 
Removing of municipal wastes by collection on a landfill site, is a routine procedure of their disposal for a long time. Hence, the aim of this study was to statistically analyze bacterial and fungal aerosol distribution at the municipal landfill site.

\section{Material and methods}

The municipal landfill site in Tarnow was opened in 1985. It is located in north-eastern part of the town. The waste disposal site was selected in a hummocky area, where ground depressions are slightly over 10 meters. At this place, the ground slightly declines to the south-east direction. The whole area of the landfill site covered approximately 12.68 ha. Three (formerly reclaimed) sectors of the total area equal to 4.8 ha are assigned for waste deposition. The fourth sector is currently used, occupying the area of 1.5 ha. It complies with all current European norms. After completion of the landfill operation at the site territory, a new technical project assumes the possibility of further landfill operation at new sectors, covering the total area of 18.5 ha. The landfill operation is carried out the using horizontal method. Thus wastes are weight followed by compaction after deposition in the appropriate sector. The wastes are deposited in layers of the thickness equal to $2 \mathrm{~m}$ in separated weekly working lots $(17 \cdot 21 \mathrm{~m})$. Periodically, the wastes are disinfected using chlorinated lime. After formation of the waste layer, it is covered with the insulating layer of soil.

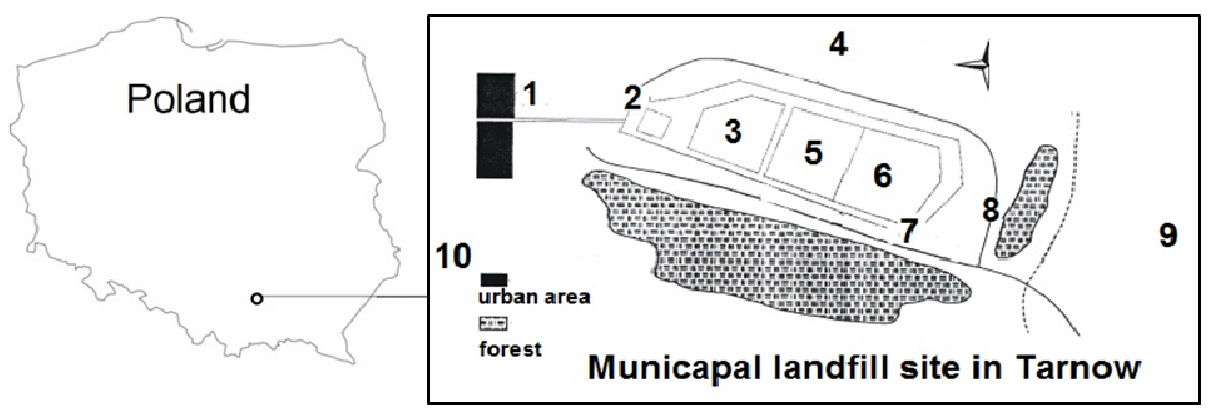

Fig. 1. Localization of sampling stands

For microbiological studies, air samples were collected each month for the 3-year period. The studies were carried out at 10 sampling stands, located along the predominating wind direction, inside and around the municipal landfill site in Tarnow (Fig. 1). This sampling stands were as follows:

No. 1 - at the open ground, located on the west from the entrance to the landfill site,

No. 2 - located near the entrance to the landfill site, near the weighing station,

No. 3 - located at the field composting plant station,

No. 4 - located at the agricultural area, on the north from the landfill site border,

No. 5 - located at the area of the active sector in the landfill site,

No. 6 - at the area of the reclaimed sector,

No. 7 - located closely to a leachate tank,

No. 8 - at the open ground in front of a row of trees, located on the east from the landfill site border, 
No. 9 - at the open ground, behind the row of trees and shrubs, located on the east from the landfill site border,

No. 10 - at the area of Tarnow city, at the distance of approximately $2 \mathrm{~km}$ on the south-west from the landfill site.

Air samples were collected using an Air Sampler SAS 90 impactor during landfill site operation. For sampling, the impactor was always set on the height of 1-1.5 m above the soil surface to collect the bioaerosol from the breathing zone. In addition temperature, relative air humidity $(\mathrm{RH})$ and the speed of wind were recorded using a weather meter Kestrel 4000 (Nielsen-Kellerman, USA) (Table 1). The air samples were collected for inoculation of the following media: Tryptic Soy Agar (TSA, Difco) with 5\% of defibred sheep blood for bacteria, Mannitol Salt Agar (MSA, bioMérieux) for staphylococci, Gauze's agar for actinomycetes and Malt Extract Agar (MEA, Difco) for fungi. The inoculated media were incubated as follows: TSA at temperature $35-37^{\circ} \mathrm{C}$ for 48 hours, MSA at $37^{\circ} \mathrm{C}$ for 48 hours, Gauze's agar at $28^{\circ} \mathrm{C}$ for 7 days, and MEA at $25^{\circ} \mathrm{C}$ for 5 days.

Table 1

Microclimatic parameters of air at sampling sites at the municipal landfill site in Tarnow and in its vicinity

\begin{tabular}{|c|c|c|c|c|c|c|}
\hline \multirow{2}{*}{$\begin{array}{c}\text { Sampling } \\
\text { site }\end{array}$} & \multicolumn{2}{|c|}{ Air temperature [ ${ }^{\mathbf{0}}$ ] } & \multicolumn{2}{c|}{ Relative humidity $(\mathbf{R H})[\%]$} & \multicolumn{2}{c|}{ Wind speed $\left[\mathbf{m}^{\cdot \mathbf{1}}\right.$ ] } \\
\cline { 2 - 7 } & Range & Median & Range & Median & Range & Median \\
\hline 1 & $-1.9-24.0$ & 15 & $57-88$ & 62 & $2-4$ & 2.1 \\
\hline 2 & $-1.8-26.6$ & 17 & $43-91$ & 68 & $1-4$ & 1.9 \\
\hline 3 & $-1.4-28.7$ & 18 & $69-84$ & 72 & $1-2$ & 1.1 \\
\hline 4 & $-0.7-25.2$ & 15 & $54-83$ & 68 & $1-3$ & 1.6 \\
\hline 5 & $-1.6-22.6$ & 14 & $41-78$ & 58 & $2-3$ & 2.2 \\
\hline 6 & $-0.4-22.1$ & 14 & $57-86$ & 68 & $1-3$ & 1.8 \\
\hline 7 & $-1.8-24.5$ & 16 & $39-81$ & 56 & $2-4$ & 2.7 \\
\hline 8 & $-0.9-25.8$ & 15 & $51-93$ & 70 & $1-2$ & 1.6 \\
\hline 9 & $-1.5-27.7$ & 17 & $42-83$ & 59 & $2-3$ & 2.3 \\
\hline 10 & $-2.1-28.7$ & 18 & $43-78$ & 64 & $2-4$ & 2.8 \\
\hline
\end{tabular}

The quantitative data were put in into the spreadsheet software Microsoft Excel 2000. Using this program, an introductory data processing was carried out (eg logarithmic transformation of the total bacterial numbers). All statistical analyses were carried out using Statistica 5.1 G. The total numbers of various groups of microorganisms were $\log$ transformed, according to the function: $y=\log _{10}(x+1)$. This transformation enables to approximate the values of respective replications to the normal distribution. Furthermore, it eliminates a positive correlation between average values and variances, which diminishes a reliability of any parametric statistical tests (eg Student's t-test and analysis of variance) [30]. To evaluate effects of the sampling site itself on the total numbers of various air microorganisms, One-way analysis of covariance (ANCOVA) was carried out, with time (months) as a covariate. The significance of differences between averages was tested using Newman-Keul's multiple range test $(p \leq 0.05)$. The simultaneous effects of the sampling site (1-st factor) and month of the year (2-nd factor) were assessed by carrying out two-way analysis of variance (ANOVA). Considering the fact that some assumptions of the parametric analysis of variance could not be fulfilled ( $e g$ additivity of the factors, homogenicity of group variances, the normal distribution of variables within groups, etc.) a nonparametric alternative of analysis of variance (for each factor separately), the Kruskal-Wallis test on ranks was carried out additionally [31]. The results of two kinds 
of analyses were concordant (in a few cases imperceptibly weaker significance level for the nonparametric test was noted). Therefore the results of Kruskal-Wallis test are not given.

Apart from the univariate analyses the analogous multivariate analyses were carried out (one-way MANCOVA and two-way MANOVA), where all the variables (after logarithmic transformation) were included. Besides of the significance level, some multivariate statistics were calculated here, Wilk's lambda (a ratio of the intragroup variance/covariance matrix to the intergroup variance/covariance matrix) and Rao's $R$ (a converted value of Wilk's lambda used for the significance level assessment).

To evaluate any possible effect of the meteorological variables on the numbers of air microorganisms at the same sampling sites, a parametric Pearson's correlation coefficient $(r)$ was calculated and its significance level was assessed. Additionally, a nonparametric Spearman's correlation coefficient on ranks $(R)$ was calculated. Considering the nature of the data (some of the variables were not measured in the continuous scale and they did not follow the normal distribution) this kind of coefficient could be more reliable than the Pearson's one. Calculations of correlation coefficients comprised air temperature, relative air humidity, the speed of wind at a moment of air sampling (independent variables - $x$ ), and microbiological (log $\mathrm{cfu} \mathrm{m}^{-3}$ air) variables (the dependent $-y$ ) for the whole period of studies.

\section{Results and discussion}

Municipal landfill sites and all inconveniences associated with them have become a noticeable problem in environmental protection last years. The waste management, especially in the case of industrial and municipal wastes, can be considered as an important and difficult task. Hence, for any correctly organized waste management, a periodical control of the landfill site effects on the natural environment and the labour environment both during landfill site's operation and some time after its reclamation, should be taken into consideration [3, 19, 32]. In this study, effects of the municipal landfill site in Tarnow on microbial quality of the atmospheric air within the landfill site and at the closest surroundings were assessed.

The statistical analyses of data obtained in this study indicate that significant differences in the numbers of airborne microbes determined at sampling sites located at different distances from the landfill site were found. It is a natural phenomenon as microorganisms and other particles raised up with aerial streams to upper layers of atmosphere, begin to sediment after travelling some distance. Air is not a suitable environment for establishing a community of characteristic microflora $[26,33]$.

The Figure 2 presents results of sampling site effects on the numbers of various groups of airborne microorganisms at the municipal landfill site in Tarnow. It was found: a) the highest corrected averages of hundreds $\mathrm{cfu} \mathrm{m}^{-3}$ air for fungi, b) high averages from several tens to several hundreds $\mathrm{cfu} \mathrm{m}^{-3}$ air for bacteria; c) moderately high averages from several to $100 \mathrm{cfu} \mathrm{m}^{-3}$ air for staphylococci, d) low averages from several to ca. $30 \mathrm{cfu} \mathrm{m}^{-3}$ air for $\beta$-hemolytic bacteria and actinomycetes; e) very low averages of several $\mathrm{cfu} \mathrm{m}^{-3}$ air for $\alpha$-hemolytic bacteria. ANCOVA indicated increasing effects of the municipal landfill site (location of the sampling site) on the numbers of airborne microorganisms, in the following order: fungi (nonsignificant effects $p=0.145)<$ actinomycetes $(p=0.0003)<\alpha$-hemolytic bacteria $\left(p=4 \cdot 10^{-6}\right)<\beta$-hemolytic bacteria $\left(p=1.5 \cdot 10^{-6}\right)<$ bacteria $\left(p=10^{-11}\right)$ $<$ staphylococci $\left(p=3 \cdot 10^{-16}\right)$. For all groups of microorganisms, except fungi, the average numbers for the site No. 5 (ie active sector of the landfill site) were significantly $(p \leq 0.05)$ 
higher compared to the lowest averages (usually the sites No. 1, 8, 9 and 10). For staphylococci, the average number at the site No. 5 (after back-transformation) was even 20 -fold higher than the lowest averages. In addition, the averages for sites No. 2, 3 and 6 were significantly higher compared to those found for the sites No. 1, 8, 9 and 10 (for bacteria, also averages of the sites No. 2 and 3; however, for $\beta$-hemolytic bacteria the average of No. 2 was equal the average of No. 5).
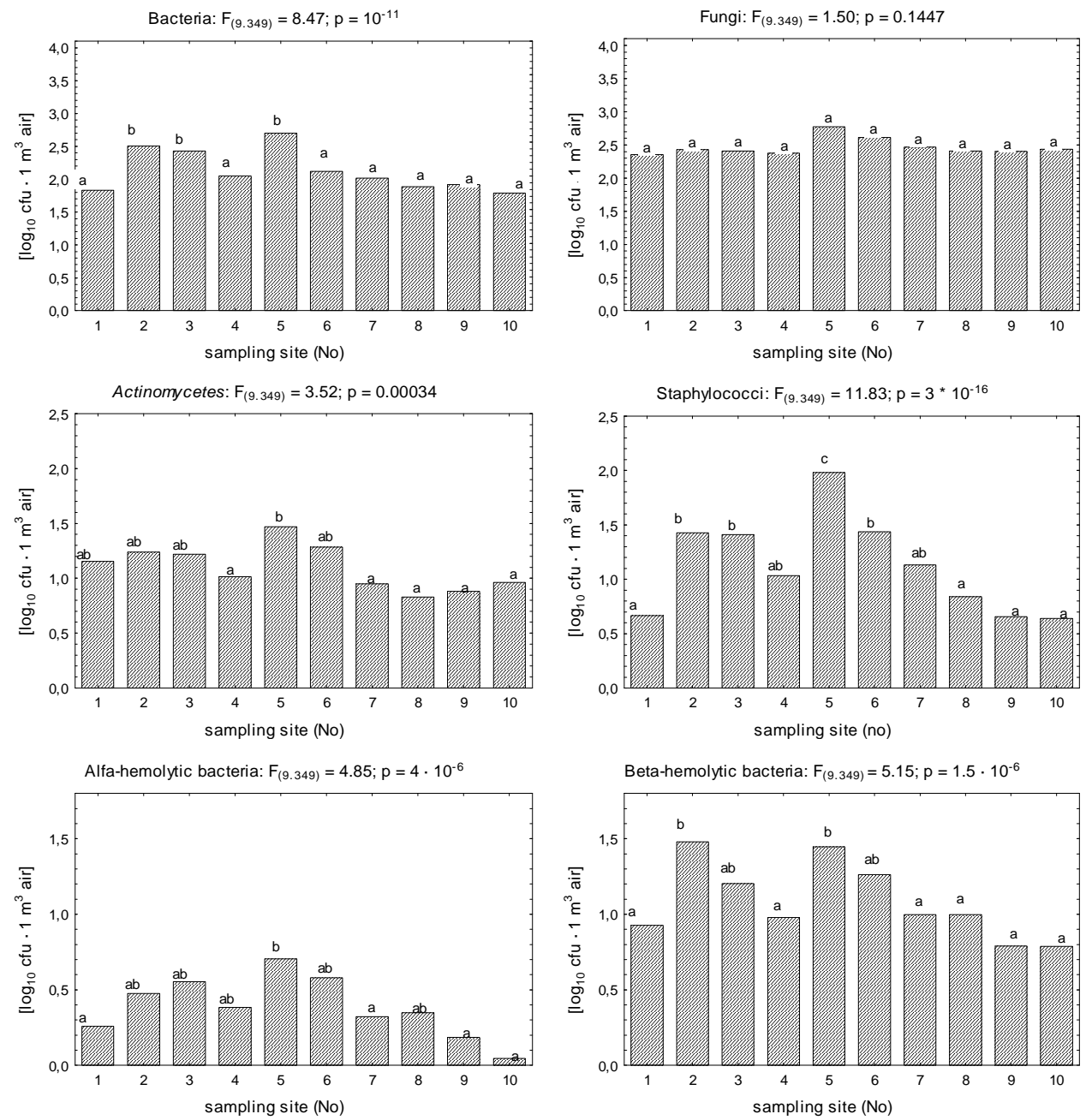

Fig. 2. Results of analysis of covariance (ANCOVA; with time as a covariate) and Newman-Keuls multiple range test $(p \leq 0.05)$ of the numbers of various groups of air microorganisms at the municipal landfill site in Tarnow and in its vicinity $\left[\log \mathrm{cfu} \mathrm{m}^{-3}\right.$ air; mean values marked with the same letter do not differ significantly $(p \leq 0.05)]$ 
Table 2

Results of two-way analysis of variance (ANOVA), comparing the effects of: I) sampling site, and II) month of the year (average for the whole period of study) on the numbers of various groups of air microorganisms at the municipal landfill site in Tarnow and in its vicinity [log $\mathrm{cfu} \mathrm{m}^{-3}$ air]

\begin{tabular}{|c|c|c|c|c|}
\hline $\begin{array}{l}\text { Source of variation } \\
\text { (see - the legend) }\end{array}$ & Variance & $\begin{array}{c}\text { Degrees } \\
\text { of freedom } \\
(d f)\end{array}$ & $\begin{array}{c}\text { F Statistic } \\
\text { (proportion } \\
\text { of variances) }\end{array}$ & $\begin{array}{c}\text { Significance } \\
\text { level } \\
(p)\end{array}$ \\
\hline \multicolumn{5}{|c|}{ A. Total number of bacteria } \\
\hline 1. Sampling site (I) $* * *$ & 3.529 & 9 & 7.827 & $4 \cdot 10^{-10}$ \\
\hline 2. Month of the year (II) $* * *$ & 2.646 & 11 & 5.868 & $2 \cdot 10^{-8}$ \\
\hline 3. Interaction $[(\mathrm{I}) \cdot(\mathrm{II})]$ & 0.242 & 99 & 0.537 & 0.9997 \\
\hline 4. Intragroup variability (error) & 0.451 & 240 & & \\
\hline \multicolumn{5}{|c|}{ B. Total number of fungi } \\
\hline 1. Sampling site (I) * & 0.600 & 9 & 3.048 & 0.0179 \\
\hline 2. Month of the year (II) $* * *$ & 7.516 & 11 & 38.199 & $<10^{-20}$ \\
\hline 3. Interaction $[(\mathrm{I}) \cdot(\mathrm{II})]$ & 0.097 & 99 & 0.492 & 0.9999 \\
\hline 4. Intragroup variability (error) & 0.492 & 240 & & \\
\hline \multicolumn{5}{|c|}{ C. Total number of actinomycetes } \\
\hline 1. Sampling site $(\mathrm{I}) * * *$ & 1.504 & 9 & 3.440 & 0.0005 \\
\hline 2. Month of the year (II) $* *$ & 1.252 & 11 & 2.864 & 0.0015 \\
\hline 3. Interaction $[(\mathrm{I}) \cdot(\mathrm{II})]$ & 0.347 & 99 & 0.793 & 0.9067 \\
\hline 4. Intragroup variability (error) & 0.437 & 240 & & \\
\hline \multicolumn{5}{|c|}{ D. Staphylococci } \\
\hline 1. Sampling site (I) *** & 7.036 & 9 & 13.299 & $3.2 \cdot 10^{-17}$ \\
\hline 2. Month of the year (II) $* * *$ & 3.497 & 11 & 6.610 & $1.24 \cdot 10^{-9}$ \\
\hline 3. Interaction $[(\mathrm{I}) \cdot(\mathrm{II})]$ & 0.456 & 99 & 0.861 & 0.8022 \\
\hline 4. Intragroup variability (error) & 0.529 & 240 & & \\
\hline \multicolumn{5}{|c|}{ E. $\alpha$-Hemolytic bacteria } \\
\hline 1. Sampling site (I) *** & 1.412 & 9 & 5.008 & $3 \cdot 10^{-6}$ \\
\hline 2. Month of the year (II) ** & 0.730 & 11 & 2.590 & 0.0040 \\
\hline 3. Interaction [(I) · (II)] & 0.276 & 99 & 0.978 & 0.5419 \\
\hline 4. Intragroup variability (error) & 0.282 & 240 & & \\
\hline \multicolumn{5}{|c|}{ F. $\beta$-Hemolytic bacteria ${ }^{++}$} \\
\hline 1. Sampling site (I) $* * *$ & 2.228 & 9 & 6.023 & $1.3 \cdot 10^{-7}$ \\
\hline 2. Month of the year (II) $* * *$ & 2.503 & 11 & 6.766 & $7 \cdot 10^{-10}$ \\
\hline 3. Interaction $[(\mathrm{I}) \cdot(\mathrm{II})]$ & 0.352 & 99 & 0.952 & 0.6053 \\
\hline 4. Intragroup variability (error) & 0.370 & 240 & & \\
\hline
\end{tabular}

Explanations: significance level of the factors (sources of variation): * $p \leq 0.05$, ** $p \leq 0.01$, *** $p \leq 0.001$; comparison of averages (statistically homogenous groups) is presented separately: a) averages for sampling site were equal to the adjusted averages from one-way analysis of covariance (homogenous groups of averages were somewhat different than those, obtained in two-way ANOVA), b) averages for months - in the analysis of the raw data (nontransformed ones), effects of the sampling site $\left[\mathrm{F}_{(9,240)}=7.63\left(p=7.6 \cdot 10^{-10}\right)\right.$ were stronger than those of month of the year $\left[\mathrm{F}_{(11,240)}=5.83\left(p=2.3 \cdot 10^{-8}\right)\right]$.

Table 2 presents results of two-way ANOVA, comparing the effects of the sampling site (I) and month of the year (II) (average for the whole period of study) on the numbers of various groups of airborne microorganisms at the municipal landfill site in Tarnów. Apart from a few exceptions ( $e g$ for the fungi, the sampling site), the effects of both factors were highly significant. Generally, the sampling site effects on microbial numbers were stronger than that of month of the year. It was found that both effects decreased in the following order: staphylococci (sampling site: $p=3.2 \cdot 10^{-17}$; month of the year: $p=1.24 \cdot 10^{-9}$ ) $>$ bacteria (sampling site: $p=4 \cdot 10^{-10}$; month of the year: $p=2 \cdot 10^{-8}$ ) $>\alpha$-hemolytic bacteria (sampling site: $p=3 \cdot 10^{-6}$; month of the year: $p=0.004$ ) $>$ actinomycetes (sampling site: $p=0.0005$, month of the year: $p=0.0015)$. For fungi, the site effect, 
however significant $(p=0.0179)$, in comparison with the highly significant time effect $\left(p<10^{-20}\right)$ can be considered as the negligible one. In the case of the $\beta$-hemolytic bacteria, the sampling time $\left(p=7 \cdot 10^{-10}\right)$ affected their numbers more strongly than the sampling site $\left(p=1.3 \cdot 10^{-7}\right)$. Taking into account that, for the untransformed data, the site effect was stronger $\left(p=7.6 \cdot 10^{-10}\right)$ than time effect $\left(p=2.3 \cdot 10^{-8}\right)$, the real effects of both factors on the $\beta$-hemolytic bacteria could be recognized as the comparable ones (Table 2 ).
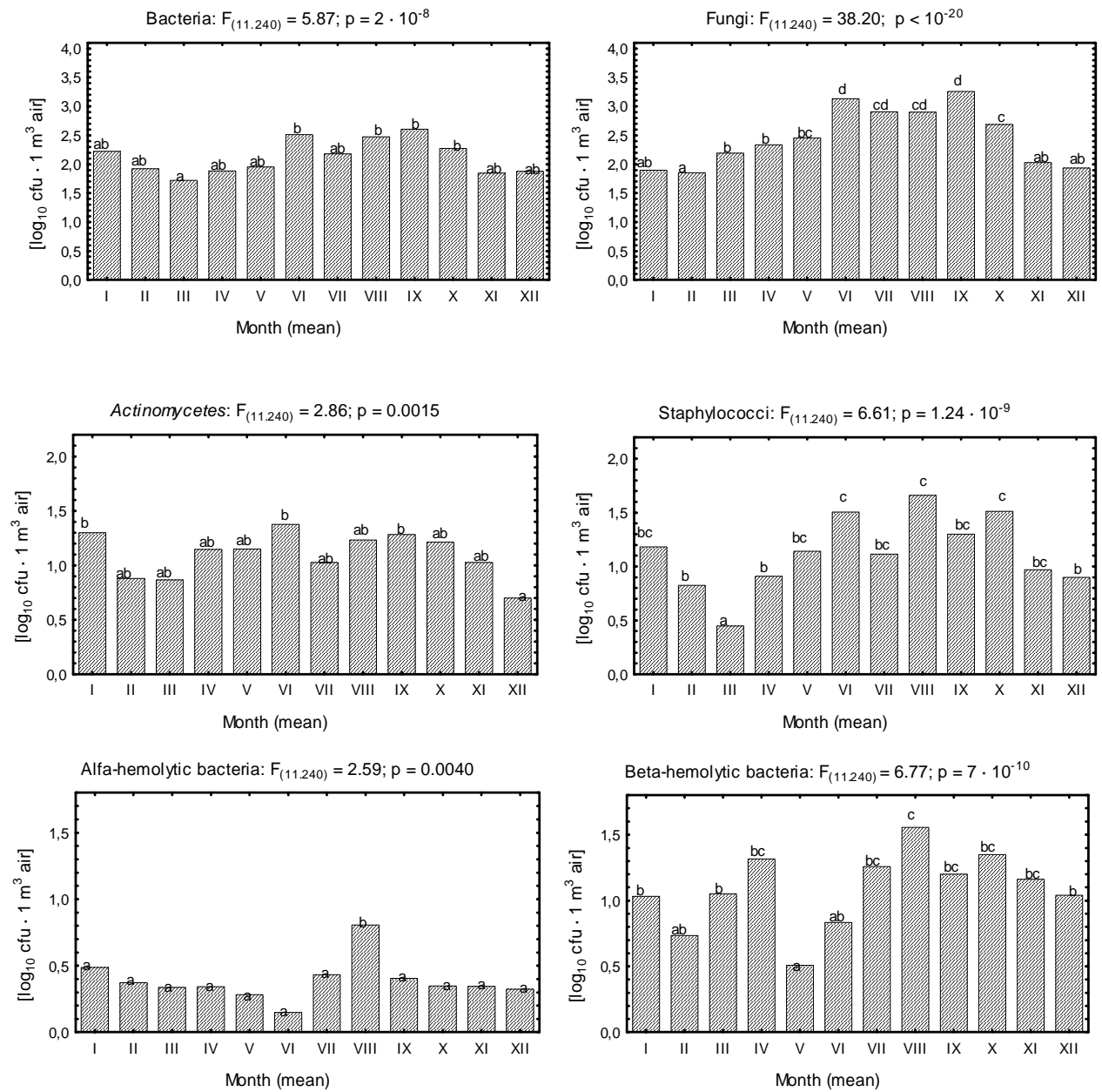

Fig. 3. Results of a comparison of averages for months (two-way ANOVA: I - sampling site, II - months) in the Newman-Keuls multiple range test $(p \leq 0.05)$ of the numbers of various groups of air microorganisms at the municipal landfill site in Tarnow and in its vicinity [ $\log \mathrm{cfu} \mathrm{m}^{-3}$ air; mean values marked with the same letter do not differ significantly $(p \leq 0.05)$ ]

However, the comparison of averages for months of the year (2-way ANOVA: I - sampling site; II - month of the year) using the Newman-Keul's multiple range test $(p \leq 0.05)$ are shown in Figure 3. In general, the airborne microorganisms were more 
numerous in summer months than during winter and early spring. For the total bacteria, fungi and actinomycetes, averages for June and September were significantly higher than those for February, March and December. The fungal numbers were almost 20-fold higher than the lowest ones, and (in contrast to bacteria and actinomycetes) at least two intermediate, statistically homogenous groups of averages could be indicated. However, for actinomycetes, the additional high was found in January. Several statistically homogenous groups of averages were also observed for staphylococci (the highest for June, August and October, the lowest for March) and for $\beta$-hemolytic bacteria (the highest for August, the lowest for May). Throughout the study, $\alpha$-hemolytic bacteria were the most frequent in August and the rarest in June (Fig. 3).

Results of: A. one-way multivariate analysis of covariance (MANCOVA; with time as a covariate), and

B. two-way multivariate analysis of variance [MANOVA; I) factor: sampling site, II) - month of the year] of the numbers of various groups of air microorganisms at the municipal landfill site in Tarnow and in its vicinity

[log cfu m $\mathrm{m}^{-3}$ air]

\begin{tabular}{|c|c|c|c|c|c|}
\hline \multicolumn{6}{|c|}{ A. one-way MANCOVA } \\
\hline \multicolumn{6}{|c|}{ I. Summary } \\
\hline Source of variation & $\begin{array}{l}\text { Wilks } \\
\text { Lambda }\end{array}$ & Rao's $R$ & $d f 1$ & $d f 2$ & $\begin{array}{c}\text { Significance } \\
\text { level } \\
(p)\end{array}$ \\
\hline Sampling site $* * *$ & 0.600 & 3.429 & 54 & 1758 & $3 \cdot 10^{-15}$ \\
\hline \multicolumn{6}{|c|}{ II. Univariate F-tests on single variables } \\
\hline Group of microorganisms & \multicolumn{3}{|c|}{$F_{(9,349)}$ (proportion of variance) } & \multicolumn{2}{|c|}{ Significance $(p)$} \\
\hline Total number of bacteria & \multicolumn{3}{|c|}{8.47} & \multicolumn{2}{|r|}{$1 \cdot 10^{-11}$} \\
\hline Total number of fungi & \multicolumn{3}{|c|}{1.50} & \multicolumn{2}{|r|}{0.1447} \\
\hline Total number of actinomycetes & \multicolumn{3}{|c|}{3.52} & \multicolumn{2}{|r|}{$3.4 \cdot 10^{-4}$} \\
\hline Staphylococci & \multicolumn{3}{|c|}{11.83} & \multicolumn{2}{|r|}{$3 \cdot 10^{-16}$} \\
\hline$\alpha$-hemolytic bacteria & \multicolumn{3}{|c|}{4.85} & \multicolumn{2}{|r|}{$4 \cdot 10^{-6}$} \\
\hline$\beta$-hemolytic bacteria & \multicolumn{3}{|c|}{$\begin{array}{l}4.85 \\
5.15\end{array}$} & \multicolumn{2}{|r|}{$1.5 \cdot 10^{-6}$} \\
\hline \multicolumn{6}{|c|}{ B. two-way MANOVA } \\
\hline \multicolumn{6}{|c|}{ I. Summary } \\
\hline Source of variation & $\begin{array}{c}\text { Wilks } \\
\text { Lambda }\end{array}$ & Rao's $R$ & $d f 1$ & $d f 2$ & $\begin{array}{c}\text { Significance } \\
\text { level } \\
(p)\end{array}$ \\
\hline Sampling site (I) *** & \multirow{3}{*}{$\begin{array}{l}0.446 \\
0.188 \\
0.188 \\
\end{array}$} & 3.826 & 54 & 1202 & $9 \cdot 10^{-18}$ \\
\hline Month of the year (II) $* * *$ & & 7.018 & 66 & 1262 & $<10^{-20}$ \\
\hline Interaction $[(\mathrm{I}) \cdot(\mathrm{II})]$ & & 0.769 & 594 & 1417 & 0.9999 \\
\hline \multicolumn{6}{|c|}{ II. Univariate F-tests on single variables } \\
\hline & \multicolumn{2}{|c|}{ Sampling site } & \multicolumn{3}{|c|}{ Month of the year } \\
\hline Group of microorganisms & $F_{(9,240)}$ & Significance $(p)$ & & & Significance $(p)$ \\
\hline Total number of bacteria & 7.827 & $4 \cdot 10^{-10}$ & & & $2 \cdot 10^{-8}$ \\
\hline Total number of fungi ${ }^{+}$) & 3.048 & 0.0179 & & & $<10^{-20}$ \\
\hline Total number of actinomycetes & 3.440 & 0.0005 & & & 0.0015 \\
\hline Staphylococci & 13.299 & $3.2 \cdot 10^{-17}$ & & & $1.24 \cdot 10^{-9}$ \\
\hline$\alpha$-hemolytic bacteria & 5.008 & $3 \cdot 10^{-6}$ & & & 0.0040 \\
\hline$\beta$-hemolytic bacteria & 6.023 & $1.3 \cdot 10^{-7}$ & & & $7 \cdot 10^{-10}$ \\
\hline
\end{tabular}

Explanations: significance level of the factors (sources of variation): $* p \leq 0.05, * * p \leq 0.01, * * * p \leq 0.001$; $d f 1$ and $d f 2$ - numbers of degrees of freedom, used for calculations of „Wilks Lambda” and „Rao's $R$ ”;

$+)$ - after excluding the variable: "total number of fungi", effects of the sampling site $\left(p=8 \cdot 10^{-18}\right)$ were stronger than those of month of the year $\left(p=5 \cdot 10^{-16}\right)$ 
The results of one-way MANCOVA and two-way MANOVA of the numbers of various groups of airborne microorganisms at the municipal landfill site are given in Table 3. In general one-way MANCOVA showed highly significant effect of the sampling site on the numbers of six various groups of air microorganisms $\left(p=3 \cdot 10^{-15}\right)$. The data would seem to suggest, that the sampling site $\left(p=9 \cdot 10^{-18}\right)$ and month of the year $\left(p<10^{-20}\right)$ highly significantly affected the occurrence of microorganisms in air. The time effect was stronger than that of the strongly than the sampling site. It is noteworthy that: a) in two-way ANOVA and MANOVA significant interaction between experimental factors was not detected, b) after excluding the variable of total fungal number from the MANOVA model, effect of the sampling site $\left(p=8 \cdot 10^{-18}\right)$ was stronger than that of month of the year $\left(p=5 \cdot 10^{-16}\right)($ Table 3$)$.

Table 4

Relationship (correlation) between meteorological data for the whole period of study [independent variables $(x)$ : average monthly atmospheric pressure, average air temperature, relative air humidity, average speed of wind, cloudiness and the sum of precipitation], and the numbers of various groups of air microorganisms in the municipal landfill site at Tarnow and in its vicinity dependent variables $(y)$, expressed as $\log \mathrm{cfu} \mathrm{m}^{-3}$ air]

\begin{tabular}{|c|c|c|c|c|c|c|}
\hline \multirow{2}{*}{$\begin{array}{c}\text { Numbers of } \\
\text { microorganisms }(\boldsymbol{y}):\end{array}$} & \multicolumn{7}{|c|}{$\begin{array}{c}\text { Meteorological data [dependent variables }(\boldsymbol{x}) \text { ] } \\
\text { Atmospheric } \\
\text { pressure }\end{array}$} & $\begin{array}{c}\text { Air } \\
\text { temperature }\end{array}$ & $\begin{array}{c}\text { Relative } \\
\text { humidity }\end{array}$ & $\begin{array}{c}\text { Speed of } \\
\text { wind }\end{array}$ & Cloudiness & $\begin{array}{c}\text { Accumulated } \\
\text { precipitation }\end{array}$ \\
\hline \multirow{2}{*}{ Bacteria } & $\bullet-0.126$ & 0.014 & -0.137 & 0.095 & -0.137 & 0.011 \\
& $\mathbf{*}-0.150$ & 0.066 & -0.057 & 0.054 & -0.143 & -0.088 \\
\hline \multirow{2}{*}{ Fungi } & $-0.599 * * *$ & $0.808 * * *$ & $-0.515 * * *$ & $0.299 * *$ & $-0.377 * * *$ & $0.795 * * *$ \\
& $-0.578 * * *$ & $0.815 * * *$ & $-0.589 * * *$ & $0.416 * * *$ & $-0.389 * * *$ & $0.746 * * *$ \\
\hline \multirow{2}{*}{ Staphylococci } & -0.107 & 0.017 & 0.054 & 0.116 & 0.122 & 0.046 \\
& -0.175 & 0.000 & 0.062 & 0.120 & 0.103 & 0.017 \\
\hline \multirow{2}{*}{ Actinomycetes } & -0.080 & 0.071 & -0.153 & 0.219 & -0.084 & 0.086 \\
& -0.163 & 0.077 & -0.135 & 0.193 & -0.120 & 0.045 \\
\hline \multirow{2}{*}{$\alpha$-hemolytic bacteria } & 0.041 & -0.018 & -0.087 & 0.038 & -0.134 & -0.058 \\
& 0.111 & -0.076 & -0.067 & -0.014 & -0.162 & -0.111 \\
\hline \multirow{2}{*}{$\beta$-hemolytic bacteria } & 0.109 & -0.111 & 0.174 & $-0.273 *$ & 0.031 & -0.146 \\
& 0.032 & 0.006 & 0.065 & -0.125 & -0.030 & -0.103 \\
\hline
\end{tabular}

Explanations: • Pearson's linear correlation coefficient $(r)$; Spearman's nonparametric correlation coefficient (correlation of ranks) $(R)$. Significance of the correlation coefficient: * $p \leq 0.05$, ** $p \leq 0.01, * * * p \leq 0.001$

The results obtained in this study indicated, that numbers of various groups of microorganisms, occurring in the air were highly dependent on the microclimatic conditions. Table 4 illustrates the correlation between the meteorological data and the airborne microbial numbers at the municipal landfill site in Tarnów. Generally there was no significant correlation noted, exception being the fungal group. The fungal numbers were significantly $(p \leq 0.05)$ positively correlated with the air temperature, sum of rainfalls and the speed of wind. However, the negative correlations were found with the atmospheric pressure, relative humidity and cloudiness. The high correlation between the sum of rainfalls and fungal numbers can be considered as weakly reliable and overestimated due to the occurrence of two mutually separated groups of data: a) low values for both variables, b) high values for both variables. The numbers of $\beta$-hemolytic bacteria were poorly correlated with the speed of wind. However, it was only found for the Pearson's parametric coefficient of linear correlation $(r)$. The Spearman's nonparametric coefficient of correlation (correlation of ranks, $R$ ) was not statistically significant, which allows us to consider the above relationship as negligible (Table 4). In Table 5, the correlations between 
the meteorological data (temperature, relative air humidity and the speed of wind) and the numbers of various groups of airborne microorganisms is presented. The numbers of almost all the groups of microorganisms (except $\alpha$-hemolytic bacteria) correlated positively with the air temperature. This relationship decreased in the following order: fungi $(r=0.599$, $R=0.616, p<<0.001)>>$ staphylococci $>$ the total bacteria $>$ actinomycetes $>\beta$-hemolytic bacteria $[r=0.098$ (nonsignificant), $R=0.155$ ( $p<0.01$ )]. For most cases the occurrence of microorganisms in air poorly negatively correlated with the relative air humidity (absolute values of $r$ and $R$ below 0.14). The negative correlations were also observed between the speed of wind and the numbers of some groups of microorganisms, the highest ones for fungi $(r=-0.371, R=-0.426, p<0.001)$ and staphylococci $[r=-0.153(p<0.01)$, $R=-0.187(p<0.001)]$.

Table 5

Relationship (correlation) between meteorological data in the period of study [independent variables $(x)$ : air temperature, relative air humidity, and speed of wind on the day of air sampling], and the numbers of various groups of air microorganisms in the municipal landfill site in Tarnow and in its vicinity dependent variables $(y)$, expressed as $\log$ cfu $\mathrm{m}^{-3}$ air]

\begin{tabular}{|c|c|c|c|}
\hline \multirow{2}{*}{$\begin{array}{c}\text { Numbers of } \\
\text { microorganisms (y): }\end{array}$} & \multicolumn{2}{|c|}{ Meteorological data [dependent variables $(\boldsymbol{x})$ ] } \\
\cline { 2 - 4 } & Air temperature & Relative humidity & Speed of wind \\
\hline \multirow{2}{*}{ Bacteria } & $\bullet 0.211 * * *$ & $-0.119 *$ & $-0.105 *$ \\
& $* 0.211 * * *$ & -0.098 & -0.103 \\
\hline \multirow{2}{*}{ Fungi } & $0.599 * * *$ & $-0.110 *$ & $-0.371 * * *$ \\
& $0.616 * * *$ & $-0.132 *$ & $-0.426 * * *$ \\
\hline \multirow{2}{*}{ Staphylococci } & $0.216 * * *$ & -0.019 & $-0.153 * *$ \\
& $0.252 * * *$ & -0.038 & $-0.187 * * *$ \\
\hline \multirow{2}{*}{ Actinomycetes } & $0.164 * *$ & $-0.106 *$ & -0.004 \\
& $0.195 * * *$ & $-0.136 * *$ & $-0.105 *$ \\
\multirow{2}{*}{$\alpha$-hemolytic bacteria } & 0.006 & 0.064 & -0.080 \\
\hline \multirow{2}{*}{$\beta$-hemolytic bacteria } & -0.024 & 0.071 & -0.065 \\
& 0.098 & -0.024 & $-0.106 *$ \\
\hline
\end{tabular}

Explanations: • Pearson's linear correlation coefficient $(r)$; Spearman's nonparametric correlation coefficient (correlation of ranks) $(R)$. Significance of the correlation coefficient: * $p \leq 0.05, * * p \leq 0.01$, *** $p \leq 0.001$

For statistical analysis of the results obtained in this study, mostly parametric methods were used, eg analysis of variance (covariance), despite the possibility of not fulfilling of all assumptions of such methods (eg additivity of the experimental factors, homogenity of the group variances, the normal distribution of variables within groups) [31]. Their use could be justified with an exploratory approach to the data analysis, where data did not have to fulfill any particular assumptions, drawn in advance, and any results of significance testing (" $p$ " values) were approximate tracers of significance only [34]. Alternatively, a nonparametric method was also applied: Kruskal-Wallis test, but its usefulness was diminished by the following limitations: a) low statistical power; b) no possibility to carry out any equivalent of two-way (and more) analysis of variance and analysis of covariance; c) unavailability (in STATISTICA) any "post-hoc" multiple range test - to compare averages [35].

Considering the above mentioned limited reliability of significance testing in the parametric statistical analyses carried out in this work (eg ANOVA and ANCOVA), we can accept that routinely taken significance level of $p \leq 0.05$ could be too weak. However more than once noted here, the values of significance level of $p \leq 10^{-6}$ (sometimes even of 
$p \leq 10^{-20}$ ) can be considered as highly significant, even for breaking down of some assumptions of parametric statistical analyses. Admittedly, some new studies similar this one, and/or being their continuation, using modern and sophisticated statistical methods ( $e g$ the generalized linear and nonlinear models), allow excluding any doubts related to the results obtained. In the present study, the relationships (correlations) between the environmental data and numbers of various groups of microorganisms were assessed quantitatively, assuming not only the existence of not only statistical relationships, but also the causal ones. Generally the positive correlation was noted, often statistically significant $(p \leq 0.05)$. However skipping a few exceptions, the correlations coefficients were not high $(<0.7)$. This result indicate that the higher contribution of random variability (not associated with correlation) than correlation explains the relationship between variables. The variability explained by correlation is described by a square of the correlation coefficient $\left(r^{2}\right)$, ie coefficient of determination, $r^{2}>0.5$ only for high values of $r(r>0.7)$ [36]. Because of this, a practical conclusion can be proposed. It is difficult to built any reliable and predicative model on the basis of data analysed in this work, which could enable to forecast any microbial air pollution on the basis of available meteorological data (eg using multiple linear or nonlinear regression), because of too poor relationships between analysed variables $\left(r<0.7\right.$ and $\left.r^{2}<0.5\right)$. The possible reasons of these relationships could result from errors in their quantitative evaluation, as well as from the lack of any elaborated reliable methods. For example, the correlation between the average speed of wind for month, and the occurrence of fungi in air during the first month of study was positive and significant $[r=0.30(p<0.01) ; R=0.42(p<0.001)]$. However, the correlation between the speed of wind, measured at the moment of sampling, and the occurrence of fungi in air during the whole period of study, was significant, but negative $[r=-0.37(p<0.001) ; R=-0.43(p<0.001)]$. A possible reason of this contradiction could be the fact, that the speed of wind was not a fully reliable and sufficient measure of the wind effect on the numbers of fungi and other microorganisms in the air. For simplification a direction of wind was not considered here. However, even taking this into account, it seems to be unsatisfactory explanation. Hence, in any model of influence of wind on the microbial numbers in air, each sampling point should be considered separately, regarding not only the direction of wind, but also the sampling point location in relation to the source of pollution (the active sector of the landfill site). Furthermore, the good predicative model besides the "waste load" should also consider other variables, eg an extent of waste microbial pollution and susceptibility of waste decomposition and/or composting.

In this study, the occurrence of various microbial groups in the air was studied. Because of a large input of labour, time and resources it was difficult to perform air monitoring for every day. As a result, it was not possible to use for the data analysis obtained any statistical methods, enabling to forecast any changes in a given variable for very short time intervals, eg the method of time series analysis. However, it is possible, when a study is based on direct counting of total number of bacteria, using an epifluorescent microscope to differentiate bacteria from any dead organic or inorganic particles and fungal spores. Airborne microbial concentrations should be estimated every day resulting in a collection of data, covering a long time of study. These data may then be subjected to the time series analysis. Consequently, the analysis could be a basis to forecast any changes in airborne bacterial and fungal numbers (counted directly) depending on the season of the year. Monitoring of bioaerosols at the waste application facilities is important for risk assessment [37]. 


\section{Conclusions}

Regarding the occurrence of various groups of microorganisms in air, this study shows adverse impact of the municipal landfill site in Tarnow on the atmospheric environment, despite the use of correct waste disposal technology. The sampling site and season of the year significantly affected the numbers of various groups of air microorganisms at the municipal landfill site and in its vicinity. For most cases, the effects of the sampling site on the microbial numbers were stronger than that of the season of the year. Generally, the effects of these factors decreased in the following order: staphylococci > bacteria > $\alpha$-hemolytic bacteria $>$ actinomycetes. For the fungi, the influence of the sampling site can be considered as the scarce, as compared with very highly significant effect of the season of the year. In the case of $\beta$-hemolytic bacteria, any real effect of both factors on the occurrence of this group of bacteria could be recognized as the comparable one. In this study, we observed higher microbial numbers at the sampling sites located in the area of the active landfill site compared to those located in its vicinity. The obtained results indicate, that despite the lack of current limits for bioaerosol levels the landfill site, even after its closing and reclamation, may still not be a suitable place for any public usage. Therefore, any regular microbiological studies of air should be carried out for a long time both at the area of landfill site and in its vicinity. These results could allow to define the time, when the landfill site become stable, regarding the numbers of microorganisms released to air.

\section{Acknowledgement}

The research was supported by the Ministry of Science and Higher Education as a research project $2 \mathrm{P} 04 \mathrm{G} 04620$.

\section{References}

[1] Ashford SA, Visvanathan C, Hausain N, Chomsurin Ch. Design and construction of engineered municipal solid waste landfills in Thailand. Waste Manag. Res. 2000;18:462-470. DOI: $10.1177 / 0734242 X 0001800507$

[2] Warith M. Bioreactor landfills experimental and field results. Waste Manage. 2002;22:7-17.

[3] Huang Ch.Y., Lee Ch.Ch., Li F.Ch., Ma Y.P., Su H.J. The seasonal distribution of bioaerosols in municipal landfill sites: a 3-yr study. Atmos Environ. 2002;36:4385-4395.

[4] Giusti L. A review of waste management practices and their impact on human health. Waste Manage. 2009;29:2227-2239. DOI: 10.1016/j.wasman.2009.03.028.

[5] Srivastava A, Singh M, Jain VK. Identification and characterization of size-segregated bioaerosols at Jawaharlal Nehru University, New Delhi. Nat Hazards. 2012;60:485-499. DOI: 10.1007/s11069-011-0022-3.

[6] Pankhurst LJ, Deacon LJ, Liu J, Drew GH, Hayes ET, Jackson S, et al. Spatial variations in airborne microorganism and endotoxin concentrations at green waste composting facilities. Int J Hyg Environ Health. 2011;214:376- 383. DOI: 10.1016/j.ijheh.2011.06.001.

[7] Górny RL. Aerozole biologiczne - rola normatywów higienicznych w ochronie środowiska i zdrowia. Medycyna Środow. 2010;13:41-51.

[8] Górny RL, Dutkiewicz J, Krysińska-Traczyk E. Size distribution of bacterial and fungal bioaerosols in indoor air. Ann Agric Environ Med. 1999;6:105-113.

[9] Kulkarni P., Baron PA, Willeke K. Aerosol Measurement: Principles, Techniques and Applications. New York: John Wiley and Sons, Inc.; 2011. DOI: 10.1002/9781118001684.ch31.

[10] Michałkiewicz M, Pruss A, Dymaczewski Z, Jeż-Walkowiak J, Kwaśna S. Microbiological air monitoring around municipal wastewater treatment plants. Polish J Environ Studies. 2011;20(5):1243-1250.

[11] Le Goff O, Godon J-J, Milferstedt K, Bacheley H, Steyer J-P, Wérya N. A new combination of microbial indicators for monitoring composting bioaerosols. Atmospheric Environ. 2012;61:428-433. DOI: 10.1016/j.atmosenv.2012.07.081. 
[12] Pankhurst LJ, Whitby C, Pawlett M, Larcombe LD, McKew B, Deacon LJ, et al. Temporal and spatial changes in the microbial bioaerosol communities in green-waste composting. FEMS Microbiol Ecol. 2012;79:229-239. DOI: 10.1111/j.1574-6941.2011.01210.x.

[13] Vilavert L, Nadal M, Figueras MJ, Domingo JL. Volatile organic compounds and bioaerosols in the vicinity of a municipal waste organic fraction treatment plant. Human health risks. Environ Sci Pollut Res. 2012;19:96-104. DOI: 10.1007/s11356-011-0547-8.

[14] Pastuszka JS, Ulfig K, Wlazło A, Brągoszewska E. Narażenie zawodowe na aerozol bakteryjny i grzybowy pracowników składowiska odpadów komunalnych na przykładzie składowiska w Sosnowcu. Ochr Powiet i Probl Odpad. 2011;45:103-113.

[15] Albrecht A, Fischer G, Brunnemann-Stubbe G, Jackel U, Kampfer P. Recommendations for study design and sampling strategies for airborne microorganisms, MVOC and odours in the surrounding of composting facilities. Int J Hyg Environ Health. 2008;211:121-131. DOI: 10.1016/j.ijheh.2007.05.004.

[16] Adamiak W, Kołwzan B, Sarowska J. Qualitative assessment of the bioaerosol In the surroundings of maślice landfill in Wrocław. Environ Protect Eng. 2001;27:27-42.

[17] Coccia AM, Gucci PMB, Lacchetti I, Paradiso R, Scaini F. Airborne microorganisms associated with waste management and recovery: biomonitoring methodologies. Ann Ist Super Santa 2010;46(3):288-292. DOI: 10.4415/Ann_10_03_11.

[18] Heo Y, Park J, Sung-il Lim S, Hor-gil Hur H, Daesung Kim D, Kihong Park K. Size-resolved culturable airborne bacteria sampled in rice field, sanitary landfill, and waste incineration sites. J Environ Monit. 2010;12:1619-1624. DOI: 10.1039/c0em00004c.

[19] Rahkonen P, Ettala M, Laukkanen M, Salkinoja-Salonen M. Airborne microbes and endotoxins in the work environment of two sanitarny landfills in Finland. Aerosol Sci Technol. 1990;13:505-513.

[20] Deportes I, Benoit-Guyod JL, Zmirou D. Hazard to man and the environment posed by the use of urban waste compost: a review. Sci Total Environ. 1995;172:197-222.

[21] Nielsen BH, Nielsen EM, Breum NO. Seasonal variation in bioaerosol exposure during biowaste collection and measurements of leaked percolate. Waste Manage Res. 2000;18:64-72. DOI: 10.1177/0734242X0001800108.

[22] Douwes J, Thorne P, Pearce N, Heederik D. Bioaerosol health effects and exposure assessment: progress and prospects. Ann Occup Hyg. 2003;47(3):187-200. DOI: 10.1093/annhyg/meg032.

[23] Lis DO, Ulfig K, Wlazło A, Pastuszka JS. Microbial air quality in office at municipal landfills. J Occup Environ Hyg. 2004,1:62-68. DOI: 10.1080/15459620490275489.

[24] Ray MR, Roychoudhury S, Mukherjee G, Roy S, Lahiri T. Respiratory and general health impairments of workers employed in a municipal solid waste disposal at an open landfill site in Delhi. Int J Hyg Environ Health. 2005;208:255-262. DOI: 10.1016/j.ijheh.2005.02.001.

[25] Atlas RM, Bartha R. Interactions between Microorganisms and Plants. Microbial. Ecology. Canada: The Benjamin/Cumings Publishing Company; 1993.

[26] Di Georgio C, Krempff A, Guiraud H, Binder P, Tiret C, Dumenil G. Atmospheric pollution by airborne microorganisms In the city of Marseilles. Atmos Environ. 1996;30:155-160.

[27] Frączek K. Microbiological studies of atmospheric air in the impact zone of the municipal landfill site in Krzyż near Tarnów. Acta Agraria et Silvestria, Ser. Agraria. 2004;42:97-105.

[28] O'Gorman CM, Fuller HT. Prevalence of culturable airborne spores of selected allergenic and pathogenic fungi in outdoor air. Atmos Environ. 2008;42:4355-4368. DOI: 10.1016/j.atmosenv.2008.01.009.

[29] Pastuszka JS, Paw KU, Lis DO, Wlazło A, Ulfig K. Bacterial and fungal aerosol in indoor environment in Upper Silesia, Poland. Atmos Environ. 2000;34:3833-3842.

[30] Fry JC. Analysis of variance and regression in aquatic bacteriology. Binary Comput Microb. 1, 83:1989.

[31] Łomnicki A. Introduction to Statistics for Natural Scientists. Warszawa: Wyd Nauk PWN; 1999.

[32] Kummer V, Thiel WR. Bioaerosols - Sources and control measures. Int J Hyg Environ Health. 2008;211:299-307. DOI: 10.1016/j.ijheh.2007.06.006.

[33] Katial RK, Zhang Y, Jones RH, Dyer PD. Atmospheric mold spore counts in relation to meteorological parameters. Int J Biometeorol. 1997;41:17-22.

[34] Palmer MW. Canonical Correspondence Analysis: some advice and guidelines. In: Kaźmierczak E, Nienartowicz A, Piernik A, Wilkon-Michalska J. editors. Computer Methods in Investigation of the Structure and Functioning the Vegetation Cover. N. Toruń, Poland: Copernicus University Press; 1998, 171-187.

[35] StatSoft, Inc. STATISTICA for Windows [Computer program manual]. Tulsa, OK: StatSoft, Inc.; 2300 East 14th Street, Tulsa, email: info@statsoftinc.com, WEB: http://www.statsoft.com: 1997.

[36] StatSoft, Inc. Electronic Statistics Textbook. Tulsa, OK: StatSoft. WEB: http://www.statsoft.com/textbook/stathome.html: 2007. 
[37] Mansour FA, El-Dohlob SM, Abdel Hameed AA, Kamel MM, El-Gendy SA. Microorganisms in the air over a bio-solid waste landfill in Egypt. J Amer Sci. 2012;8(4):573-579.

\title{
ANALIZA STATYSTYCZNA ZAWARTOŚCI BIOAEROZOLU W OBRĘBIE SKŁADOWISKA ODPADÓW KOMUNALNYCH
}

\author{
${ }^{1}$ Katedra Mikrobiologii, Uniwersytet Rolniczy im. Hugona Kołłątaja w Krakowie \\ ${ }^{2}$ Katedra Mikrobiologii, Uniwersytet im. Mikołaja Kopernika w Toruniu \\ ${ }^{3}$ Katedra Ochrony Środowiska Rolniczego, Uniwersytet Rolniczy im. Hugona Kołłątaja w Krakowie
}

\begin{abstract}
Abstrakt: Celem badań była ocena jakości mikrobiologicznej powietrza na terenie składowiska odpadów komunalnych i w jego otoczeniu. Przeprowadzone badania potwierdzają negatywny wpływ składowiska odpadów komunalnych w Tarnowie na środowisko atmosferyczne pomimo stosowania prawidłowych technik składowania odpadów. Miejsce poboru próbek powietrza i pora roku oddziaływały wysoce istotnie na liczebność różnych grup drobnoustrojów powietrza na składowisku odpadów komunalnych oraz w jego okolicy. W większości przypadków oddziaływanie stanowiska pomiarowego na ilość liczbę drobnoustrojów było silniejsze niż pora roku. Obserwowano wyższe ilości liczebności mikroorganizmów na stanowiskach pomiarowych zlokalizowanych na obszarze czynnego składowiska niż położonych w jego sąsiedztwie. Uzyskane wyniki wskazują, że, mimo braku aktualnie opracowanych wartości progowych dla bioaerozoli, to składowisko odpadów nawet po zamknięciu i rekultywacji może nie być jeszcze odpowiednim miejscem użytku publicznego. Dlatego też należy prowadzić regularne badania mikrobiologiczne powietrza na terenie i wokół składowiska w dłuższym okresie, które pozwolą na określenie czasu, kiedy składowisko staje się stabilne pod względem ilości liczby uwalnianych do powietrza mikroorganizmów.
\end{abstract}

Słowa kluczowe: bioaerozol, środowisko atmosferyczne, składowisko odpadów komunalnych, mikroorganizmy 